\title{
Erratum to: Mapping tropical forest cover and deforestation using synthetic aperture radar (SAR) images
}

\author{
M. Mahmudur Rahman • \\ Josaphat Tetuko Sri Sumantyo
}

Published online: 18 August 2010

(C) The Author(s) 2010. This article is published with open access at Springerlink.com

\section{Erratum to: Appl Geomat}

\section{DOI 10.1007/s12518-010-0026-9}

During the proof correction procedure the following corrections were misinterpreted:

1. Abstract, line 17: "Topographic" should be "Topography"

2. Conclusion, lines 1-2: "dual polarization and quadSAR data" should read "dual and quad-polarization SAR data"

3. Conclusion, paragraph between Fig. 5 and Table 5: "quad-polarization PALSAR polarimetric data" should read "quad-polarization PALSAR data"

Open Access This article is distributed under the terms of the Creative Commons Attribution Noncommercial License which permits any noncommercial use, distribution, and reproduction in any medium, provided the original author(s) and source are credited.

The online version of the original article can be found at http://dx.doi. org/10.1007/s12518-010-0026-9.

M. M. Rahman $(\bowtie) \cdot J$. T. S. Sumantyo

Microwave Remote Sensing Laboratory, Center for

Environmental Remote Sensing, Chiba University,

1-33, Yayoi, Inage,

Chiba 263-8522, Japan

e-mail: mahmud@sparrso.gov.bd

Present Address:

M. M. Rahman

Bangladesh Space Research and Remote

Sensing Organization (SPARRSO),

Agargaon, Sher-E-Bangla Nagar,

Dhaka 1207, Bangladesh 